\title{
DOMINANCIA, COMPOSICIÓN QUÍMICA-NUTRITIVA DE ESPECIES FORRAJERAS Y FITOMASA POTENCIAL EN UNA SELVA SECUNDARIA
}

\section{DOMINANCE, CHEMICAL-NUTRITIONAL COMPOSITION, AND POTENTIAL PHYTOMASS OF FODDER SPECIES IN A SECONDARY RAINFOREST}

Tania Gómez-Fuentes-Galindo ${ }^{1}$, Carlos González-Rebeles ${ }^{1 *}$, Silvia López-Ortiz ${ }^{2}$, J. Carlos Ku-Vera ${ }^{3}$, C. de Jesús Albor-Pinto ${ }^{3}$, J. Roberto Sangines-García ${ }^{4}$

\begin{abstract}
${ }^{1}$ Universidad Nacional Autónoma de México. Facultad de Medicina Veterinaria y Zootecnia. Ciudad Universitaria (anyagof@yahoo.com.mx) (grebeles@unam.mx). ${ }^{2}$ Colegio de Postgraduados, Campus Veracruz (silvialopez@colpos.mx). ${ }^{3}$ Universidad Autónoma de Yucatán. Facultad de Medicina Veterinaria y Zootecnia. Campus de Ciencias Biológicas y Agropecuarias (kvera@uady.mx) (c.albor@hotmail.com). ${ }^{4}$ Tecnológico de Conkal. Avenida Tecnológico s/n Conkal, Yucatán (roberto.sangines@itconkal.edu.mx).
\end{abstract}

\section{RESUMEN}

Se determinó la relación entre abundancia, dominancia y similitud de especies forrajeras con la calidad nutritiva y cantidad de fitomasa potencial para la alimentación de bovinos en sitios con vegetación forestal, arbustiva y herbácea en la época seca y la lluvia. Se encontraron 54 especies forrajeras agrupadas en 21 familias (dominando Fabacea). La abundancia de leńosas forrajeras fue mayor en temporada de lluvias en la comunidad forestal $(p<0.0001 ; 52.8 \pm 11.4)$ y en la de secas en la arbustiva $(p=0.002 ; 14.80 \pm 3.09)$. La similitud entre comunidades varió de 0.27 a 0.54 . Las especies forrajeras dominantes de la comunidad forestal en lluvias presentaron altos valores nutricionales, degradabilidad ruminal (65.9-89.0 \%) y energía metabolizable (9.35-11.52 MJ/kg MS). El mayor contenido de taninos fue en Bauhinia divaricata $(12.75 \%)$. La fitomasa potencial rindió 3272 y 1454 $\mathrm{kg}$ MS/ha en lluvias y secas, respectivamente, y fue mayor en herbáceas $(\mathrm{P}<0.0001 ; 3977 \pm 2299$ y $2451 \pm 3336$, respectivamente). Se encontró una gran diversidad de especies forrajeras, diferentes en cada comunidad vegetal, y que difieren en calidad químico-nutritiva. En su conjunto, la fitomasa potencial de todos los estratos y la variedad de nutrientes que las especies contienen se complementan para alimentar bovinos a lo largo del ańo.

Palabras clave: nutrientes, diversidad, vegetación nativa, bovinos.

* Autor responsable * Author for correspondence. Recibido: mayo, 2016. Aprobado: noviembre, 2016. Publicado como ARTÍCULO en ASyD 14: 617-634. 2017.

\section{AbSTRact}

The relationship between abundance, dominance and similarity of fodder species with the nutritional quality and quantity of potential phytomass for feeding bovines was determined, in sites with forest, shrub and herbaceous vegetation in dry and rain season. Fifty-four (54) fodder species were found grouped into 21 families (with Fabacea dominating). The abundance of woody fodder was higher in the rain season in the forest community $(p<0.0001$; $52.8 \pm 11.4)$ and in the dry season in the shrub community $(p=0.002 ; 14.80 \pm 3.09)$. The similarity between communities varied from 0.27 to 0.54 . The dominating fodder species of the forest community in the rain season presented high nutritional values, ruminal degradability (65.9-89.0 \%) and metabolizable energy (9.35-11.52 MJ/kg DM). The highest content of tannins was in Baubinia divaricata (12.75\%). The potential phytomass yielded 3272 and $1454 \mathrm{~kg} \mathrm{DM} / \mathrm{ha}$ in the rain and dry seasons, respectively, and was higher in herbs ( $\mathrm{P}<0.0001 ; 3977 \pm 2299$ and $2451 \pm 3336$, respectively). A large diversity of fodder species was found, different in each plant community, and which differ in chemical-nutritional quality. As a whole, the potential phytomass of all the strata and the variety of nutrients that the species contain complement each other to feed bovines throughout the year.

Key words: nutrients, diversity, native vegetation, bovines.

\section{INTRODUCTION}

$\mathrm{E}$ xtensive livestock production is practiced approximately in $30 \%$ of the rainforests or tropical forests of the world (FAO, 2009) 


\section{INTRODUCCIÓN}

$\mathrm{L}$ a ganadería extensiva se practica aproximadamente en el $30 \%$ de las selvas o bosques tropicales del mundo (FAO, 2009) y se asocia con el cambio de uso del suelo (FAO, 2013). Las prácticas ganaderas relacionadas con el cambio de uso del suelo, ocasionan deforestación, disminución de la biodiversidad, de los servicios ambientales y alteran los ciclos biogeoquímicos, contribuyendo al cambio climático global (LEAD, 2006). Ante esta problemática es imperativa la reconversión ganadera hacia sistemas de producción amigables con el ambiente donde se reemplacen los monocultivos de gramíneas de variedades mejoradas por pastos con menor requerimiento hídrico y especies vegetales perennes, así como prácticas de ramoneo en vegetación secundaria (Ferguson et al., 2013; Nahed et al., 2013).

Tradicionalmente, los sistemas de producción animal extensivos se basan en monocultivos de gramíneas para proveer de biomasa y nutrientes al ganado (Ayala et al., 2006), sin considerar que para establecer monocultivos se desplaza la vegetación nativa con potencial forrajero (Flores y Bautista, 2012). Se ha documentado que estas especies pueden contener proteína cruda superior al $12 \%$ de la MS, amplios rangos de fibra detergente neutra y degradabilidad ruminal aceptable (Flores y Bautista, 2012; Rojas et al., 2016). A su calidad químico-nutritiva se asocia la presencia de metabolitos secundarios que tienen aplicaciones biológicas importantes en la nutrición y salud animal; como los taninos condensados, capaces de disminuir la carga de parásitos intestinales y las emisiones de metano entérico de los rumiantes (Mueller, 2006; Gerber et al., 2013). Sin embargo, la capacidad de carga animal de estos sitios donde se mantiene la vegetación arbórea asociada a gramíneas es aún una incógnita por resolver, de manera que sea posible distribuir el manejo de la biomasa forrajera a través del año. Por otra parte, se ha propuesto que el forraje disponible de la vegetación natural en la Península de Yucatán puede variar de 821 hasta 2 $463 \mathrm{~kg} \mathrm{MS} / \mathrm{ha} /$ año, con una capacidad variable de la carga animal entre 0.16 y $0.50 \mathrm{UA} / \mathrm{ha} /$ año, variación asociada al tipo de vegetación y de suelo (CICC, 2009; Escamilla et al., 2005). Se conoce poco sobre su productividad, las relaciones entre el forraje potencial para el ganado y los cambios en la abundancia de las especies nativas a través de diferentes etapas and is associated with the change in land use (FAO, 2013). The husbandry practices related to the change in land use cause deforestation, decrease in biodiversity and in environmental services, and alter the biogeochemical cycles, contributing to global climate change (LEAD, 2006). Facing this problematic, livestock reconversion is imperative toward environment-friendly production systems where monocrops of improved varieties of grasses are replaced by grasses with lower water requirements and perennial plant species, as well as the grazing practices in secondary vegetation (Ferguson et al., 2013; Nahed et al., 2013).

Traditionally, the extensive livestock production systems are based on grass monocrops to provide biomass and nutrients to the cattle (Ayala et al., 2006), without taking into account that in order to establish monocrops the native vegetation with fodder potential is displaced (Flores and Bautista, 2012). It has been documented that these species can contain raw protein above $12 \%$ of the dry matter (DM), wide ranges of neutral detergent fiber and acceptable ruminal degradability (Flores and Bautista, 2012; Rojas et al., 2016). The presence of secondary metabolites, which have important biological applications in animal nutrition and health, is associated to their chemical-nutritional quality; such is the case of condensed tannins which are capable of decreasing the load of intestinal parasites and the emissions of enteric methane from ruminants (Mueller, 2006; Gerber et al., 2013). However, the animal load capacity of these sites where the tree vegetation associated to grasses is kept is still a mystery to be solved, so it is possible to distribute the management of fodder biomass throughout the year. On the other hand, it has been suggested that the fodder available from natural vegetation in the Yucatán Peninsula can vary from 821 to 2463 DM/ ha/year, with a variable animal load capacity between 0.16 and $0.50 \mathrm{UA} / \mathrm{ha} / \mathrm{year}$, variation associated to the type of vegetation and soil (CICC, 2009; Escamilla $e t$ al., 2005). Little is understood about its productivity, the relationships between potential fodder for livestock and the changes in abundance of native species through different successional stages of the medium sub-deciduous rainforest, so diagnoses are required that allow understanding these relationships in order to achieve the optimization of the exploitation and management of available biomass 
sucesionales de la selva mediana subcaducifolia, por lo que se requiere hacer diagnósticos que permitan conocer dichas relaciones para lograr la optimización del aprovechamiento y manejo de la biomasa disponibles con fines forrajeros dirigidos hacia la preservación de las comunidades vegetales. Por lo anterior, el objetivo de este trabajo fue determinar la relación entre la abundancia y la similitud de plantas con potencial forrajero tanto leñosas como herbáceas de la vegetación secundaria, con la calidad nutritiva y cantidad de forraje potencial para ganado bovino. La hipótesis que se plantea es que a mayor abundancia de plantas con potencial forrajero en la vegetación secundaria habrá mayor complementación de nutrientes y mayor fitomasa potencial para el ganado.

\section{Materiales y Métodos}

\section{Localización y descripción del área de estudio}

La investigación se realizó durante 2013 y 2014 en el municipio de Tzucacab, Yucatán, México, entre las coordenadas $19^{\circ} 55^{\prime} 823^{\prime \prime}$ y $20^{\circ} 00^{\prime} 873^{\prime \prime} \mathrm{N}$ y $88^{\circ} 57^{\prime} 818^{\prime \prime}$ y $89^{\circ} 02^{\prime} 580^{\prime \prime} \mathrm{O}$, con $165 \mathrm{~m}$ de altitud promedio. El suelo es de origen kárstico, caracterizado por la presencia de Leptosol, Cambisol y Luvisol (Flores y Bautista, 2005). El clima es cálido subhúmedo $\left(\mathrm{Aw}_{0}\right)$ (García y CONABIO, 1998). La temperatura media anual durante 2015 fue $27.5^{\circ} \mathrm{C}$ y la precipitación anual acumulada, $1210 \mathrm{~mm}$ (CONAGUA, 2015). El tipo de vegetación es selva mediana subcaducifolia secundaria (Flores y Espejel, 1994; Zamora et al., 2009). Se evaluaron tres unidades de producción bovina (UPB) en un radio de $15 \mathrm{~km}$. Las UPB estuvieron conformadas por animales de doble propósito (Bos taurus x Bos indicus), en su mayoría vacas $(75-85 \%)$. El tamaño de los potreros osciló entre 10 y $40 \mathrm{ha}$, con un periodo de descanso de pastoreo de entre uno y tres meses. La alimentación de los bovinos se basó en el consumo de gramíneas y vegetación secundaria a lo largo de todo el año. Las superficie y carga animal de las UPB fueron $130 \mathrm{y}$ 0.33; 108 y 0.19 y 800 y 0.10 ; hectáreas y UA / ha / año, respectivamente, considerando una UA equivalente a un bovino de $450 \mathrm{~kg}$ de peso vivo.

Con base en la descripción de la sucesión vegetal de Flores (2001) se distinguieron a las comunidades forestal, arbustiva y herbácea. La Comunidad Forestal (CF) se caracterizó por la presencia de árboles con with fodder use directed toward the conservation of plant communities. Because of this, the objective of this study was to determine the relationship between abundance and similarity of plants with fodder potential, both woody and herbaceous, in the secondary vegetation, with the nutritional quality and quantity of potential fodder for bovine livestock. The hypothesis set out is that with higher abundance of plants with fodder potential in the secondary vegetation there will be higher complementation of nutrients and higher potential phytomass for the cattle.

\section{Materials AND Méthods}

\section{Location and description of the study area}

The research was carried out during 2013 and 2014 in the municipality of Tzucacab, Yucatán, México, between coordinates $19^{\circ} 55^{\prime} 823^{\prime \prime}$ and $20^{\circ} 00^{\prime} 873^{\prime \prime} \mathrm{N}$ and $88^{\circ} 57^{\prime} 818^{\prime \prime}$ and $89^{\circ} 02^{\prime} 580^{\prime \prime} \mathrm{W}$, with $165 \mathrm{~m}$ of average altitude. The soil is of karstic origin, characterized by the presence of Leptosol, Cambisol and Luvisol (Flores and Bautista, 2005). The climate is sub-humid warm $\left(\mathrm{Aw}_{0}\right)$ (García and CONABIO, 1998). The mean annual temperature during 2015 was $27.5^{\circ} \mathrm{C}$ and the accumulated annual precipitation, $1210 \mathrm{~mm}$ (CONAGUA, 2015). The type of vegetation is secondary medium sub-deciduous rainforest (Flores and Espejel, 1994; Zamora et al., 2009). Three bovine production units (BPUs) were evaluated within a radius of $15 \mathrm{~km}$. The BPUs were made up of double-purpose animals (Box Taurus $\mathrm{x}$ Bos indicus), in their majority cows (75-85 $\%)$. The size of the pastures ranged between 10 and $40 \mathrm{ha}$, with a resting period from grazing of between one and three months. The cattle diet was based on the consumption of grasses and secondary vegetation throughout the year. The surface and animal load of the BPUs were 130 and 0.33, 108 and 0.19 , and 800 and 0.10 hectares and UA/ha/year, respectively, considering UA equivalent to one bovine of $450 \mathrm{~kg}$ live weight.

Based on the description of the plant succession by Flores (2001), the forest, shrub and herb communities are distinguished. The Forest Community (FC) was characterized by the presence of trees with more than $8 \mathrm{~m}$ of height, diameter at breast height $(\mathrm{DBH})$ higher or equal to $10 \mathrm{~cm}$ and 10 to 15 years of 
más de $8 \mathrm{~m}$ de altura, diámetro a la altura del pecho (DAP) mayor o igual a $10 \mathrm{~cm}$ y de 10 a 15 años de abandono. En la Comunidad Arbustiva (CA) se encontraron árboles menores a $4 \mathrm{~m}$ de altura, DAP menor a $10 \mathrm{~cm}$, con dominancia de arbustivas y de dos a diez años de abandono y Comunidad Herbácea $(\mathrm{CH})$, con presencia de herbáceas, gramíneas, lianas o bejucos y de dos a cuatro años de abandono. Una de las UPB no tuvo $\mathrm{CH}$ y otra la perdió en secas.

\section{Descripción del estudio}

Se caracterizó la vegetación de una selva mediana subcaducifolia en distintas etapas sucesionales para conocer el nivel de dominancia de las especies forrajeras, a través del índice del valor de importancia relativa (VIR). Se analizaron las diferencias en la abundancia de especies forrajeras entre comunidades vegetales. Se estimó el contenido de la materia seca de la fitomasa potencial en los estratos leñoso y herbáceo de la CF, CA y CH durante la época de lluvias (octubre y noviembre de 2013) y secas (abril y mayo de 2014). Se determinaron los contenidos químico-nutritivos, degradabilidad ruminal in situ de la materia seca a las 48 h y la concentración de energía metabolizable de las especies forrajeras recolectadas durante la época de lluvias en el área de estudio.

\section{Muestreo de la vegetación}

Se evaluó un primer grupo de variables conformado por la riqueza, abundancia, frecuencia, DAP y cobertura de todas las plantas encontradas, con la finalidad de estimar el VIR y conocer el nivel de dominancia de las especies forrajeras. Para lo anterior, en cada tipo de comunidad vegetal se recorrieron de manera sistemática (Bautista et al., 2004) $75 \mathrm{~m}$ hacia el Oeste. Al término del recorrido se inció el establecimiento de los marcos de muestreo, con una distancia de 10 metros entre cada uno. Se colocaron cuatro marcos de muestreo de $16 \mathrm{~m}^{2}(4 \times 4 \mathrm{~m})$ para el estrato leñoso, con marcos anidados de $1 \mathrm{~m}^{2}$ para el estrato herbáceo (Mueller-Dombois y Ellenberg, 1974; Bonham, 1989). En la CF y CA se colocaron en total 24 marcos anidados por comunidad y en la $\mathrm{CH}$ solo se colocaron 12 , debido a la ausencia del estrato leńoso y a que no siempre hubo una $\mathrm{CH}$ en las UPB. abandonment. In the Shrub Community (SC) trees below $4 \mathrm{~m}$ of height were found, DBH lower than 10 $\mathrm{cm}$, with shrub dominance and two to ten years of abandonment; and in the Herb Community (HC), with presence of herbs, grasses, vines or lianas and two to four years of abandonment. One of the BPUs did not have $\mathrm{HC}$ and another one lost it during the dry season.

\section{Description of the study}

The vegetation of a medium sub-deciduous rainforest in different successional stages was characterized to understand the level of dominance of the fodder species, through the index of relative value of importance (RVI). The differences in abundance of fodder species between plant communities were analyzed. The dry matter content of the potential phytomass was estimated in the woody and herbaceous strata of the FC, SC and $\mathrm{HC}$ during the rainy season (October and November 2013) and dry season (April and May 2014). The chemical-nutritional contents, in situ ruminal degradability of the dry matter, and the concentration of metabolizable energy of the fodder species collected were determined at $48 \mathrm{~h}$ during the rainy season in the study area.

\section{Sampling of the vegetation}

A first group of variables made up of the wealth, abundance, frequency, $\mathrm{DBH}$ and coverage of all the plants found was evaluated, with the aim of estimating the RVI and understanding the level of dominance of the fodder species. For this purpose, in each type of plant community $75 \mathrm{~m}$ to the west were visited systematically (Bautista et al., 2004). At the end of the visit the establishment of sampling frames began, with a distance of 10 meters between each. Four sampling frames of $16 \mathrm{~m}^{2}(4 \times 4 \mathrm{~m})$ were placed for the woody stratum, with nested frames of $1 \mathrm{~m}^{2}$ for the herbaceous stratum (Mueller-Dombois and Ellenberg, 1974; Bonham, 1989). In the FC and SC, 24 nested frames were placed in total per community and in the $\mathrm{HC}$ only 12 were placed, due to the absence of the woody stratum and because there wasn't always a $\mathrm{HC}$ in the BPUs.

The representativeness of the sample was calculated through an accumulation curve of species using the Chao 2 Mean model (Estimate $S$ version 
Se calculó la representatividad del muestreo mediante una curva de acumulación de especies empleando el modelo de Chao 2 Mean (Estimate $S$ versión 9.1.0, Colwell 2013), que es más adecuado cuando se cuenta con datos de presencia-ausencia de las especies (Álvarez et al., 2006). Las especies se identificaron en el herbario "Alfredo Barrera Marín" de la Facultad de Medicina Veterinaria y Zootecnia de la Universidad Autónoma de Yucatán (FMVZUADY).

\section{Fitomasa potencial}

Se evaluó un segundo grupo de variables constituido por la fitomasa potencial de la vegetación secundaria y la degradabilidad ruminal y la concentración de energía metabolizable de especies forrajeras. La fitomasa potencial se recolectó en los marcos de muestreo de $1 \mathrm{~m}^{2}$ previamente establecidos, con fines de describir detalladamente el potencial forrajero de los estratos de las comunidades vegetales. Se consideró fitomasa potencial aquella que estuvo al alcance de los animales (Bello et al., 2001). Para su muestreo se defoliaron manualmente follaje, frutos, flores y tallos tiernos encontrados dentro de los marcos de $1 \mathrm{~m}^{2}$ previamente establecidos y a una altura entre 5 y $170 \mathrm{~cm}$. El material colectado se secó a $60^{\circ} \mathrm{C}$ en una estufa de aire forzado durante $72 \mathrm{~h}$ (AOAC, 2000).

\section{Análisis nutricionales}

El propósito de analizar la composición químiconutritiva y determinar la degradabilidad ruminal y concentración de energía metabolizable fue describir las características nutricionales de las especies forrajeras encontradas en la selva mediana subcaducifolia consumida por bovinos. Se incluyeron todas las plantas presentes en el estrato de 5 a $170 \mathrm{~cm}$ de altura, que en trabajos previos se han identificado como forrajeras (Sosa et al., 2000; Ayala et al., 2006; Alonso et al., 2009; Velázquez et al., 2010; Flores y Bautista, 2012). La colecta se realizó en noviembre de 2013, considerando que la vegetación dominante se encontraría en floración (Flores, 2001), reflejando así niveles óptimos de nutrientes para el ganado (Ayala et al., 2006). Se cortó manualmente $1 \mathrm{~kg}$ de hojas, frutos y tallos tiernos de las especies listadas como forrajeras y presentes en los sitios de muestreo.
9.1.0, Colwell 2013), which is more adequate when there are data of presence-absence of the species (Álvarez et al., 2006). The species were identified in the "Alfredo Barrera Marín" herbarium of the School of Veterinarian Medicine and Animal Husbandry of the Universidad Autónoma de Yucatán (Facultad de Medicina Veterinaria y Zootecnia de la Universidad Autónoma de Yucatán, FMVZ-UADY).

\section{Potential phytomass}

A second group of variables made up of the potential phytomass of the secondary vegetation and ruminal degradability was evaluated, and the concentration of metabolizable energy of fodder species. The potential phytomass was collected in the sampling frames of $1 \mathrm{~m}^{2}$ previously established, with the objective of describing in detail the fodder potential of the plant community strata. The potential phytomass which was in reach of the animals was considered (Bello et al., 2001). For their sampling, fodder, fruits, flowers and tender stems were defoliated manually within the $1 \mathrm{~m}^{2}$ frames previously established and at a height of between 5 and $170 \mathrm{~cm}$. The material collected was dried at $60{ }^{\circ} \mathrm{C}$ in a forced air stove during $72 \mathrm{~h}$ (AOAC, 2000).

\section{Nutritional analysis}

The purpose of analyzing the chemicalnutritional composition and determining the ruminal degradability and concentration of metabolizable energy was to describe the nutritional characteristics of the fodder species found in the medium sub-deciduous rainforest consumed by bovines. All the plants present in the stratum of 5 to $170 \mathrm{~cm}$ height were included, which in previous works had been identified as fodder species (Sosa et al., 2000; Ayala et al., 2006; Alonso et al., 2009; Velázquez et al., 2010; Flores and Bautista, 2012). The collection was carried out in November 2013, considering that the dominant vegetation would be flowering (Flores, 2001), thus reflecting optimal levels of nutrients for the livestock (Ayala et al., 2006). Manually, $1 \mathrm{~kg}$ of leaves, fruits and tender stems of the species listed as fodder and present in the sampling sites was cut. 


\section{Composición químico-nutritiva de especies forrajeras}

Se determinó la fibra detergente neutra (FDN) mediante bolsas de filtrado, aplicando el método 6 de Ankom Technology (Ankom Tecnology A200 y A200I) (Van Soest et al., 1991), proteína cruda (PC $\mathrm{N} \times 6.25)$ con un analizador elemental $(\mathrm{C}, \mathrm{N})$, Lecco CN-2000 serie 3740 (Lecco, 2013) y taninos condensados (TC), utilizando el método colorimétrico de Vainillina-Ácido Clorhídrico (Makkar y Becker, 1993) a 20 especies forrajeras dominantes, identificadas así después de calcular el VIR. Los resultados de TC deberán tomarse con cautela, ya que no se utilizó nitrógeno líquido durante el muestreo ni se refrigeró posteriormente para la conservación de las muestras.

\section{Determinación de la degradabilidad ruminal y concentración de energía metabolizable}

A las 48 horas se realizaron ensayos de degradabilidad ruminal in situ de la materia seca a 16 de las especies forrajeras más dominantes. Se utilizó la técnica de la bolsa de nylon con abertura de poro de $53 \mu \mathrm{m}$ (Ørskov et al., 1980) en dos vacas (430 kg de peso vivo) canuladas en el rumen y alimentadas con $20 \mathrm{~kg}$ de Pennisetum purpureum (cv Taiwán), 4 $\mathrm{kg}$ de Leucaena leucocephala y $1 \mathrm{~kg}$ de concentrado ( $13.5 \%$ de PC). Se estimó la energía metabolizable (EM), utilizando la Degradabilidad in situ de la materia seca (DisMS) con la ecuación (Orskov et al., 1980):

$\mathrm{EM}(\mathrm{MJ} / \mathrm{kg})=(2.27563+0.1073) \times \mathrm{D} i \mathrm{MS}$

\section{Análisis de datos}

Para describir los niveles de dominancia se estimó el VIR (Mueller-Dombois y Ellenberg, 1974) de los estratos herbáceo y leñoso de todas las especies (forrajeras y no forrajeras). Los valores de abundancia, frecuencia, cobertura y DAP registrados en las unidades de producción se integraron en un solo grupo de datos para la CF, otro para la CA y un último para la $\mathrm{CH}$. Se seleccionó a las especies forrajeras con mayor dominancia para someterse a análisis químico-nutricional.

\section{Chemical-nutritional composition of fodder species}

The neutral detergent fiber (NDF) was determined through filtered bags, applying method 6 from Ankom Technology (Ankom Tecnology A200 and A200I) (Van Soest et al., 1991), raw protein $(\mathrm{RP} \mathrm{N} \times 6.25)$ with an elemental analyzer (C, N), Lecco CN-2000 series 3740 (Lecco, 2013) and condensed tannins (CT), using the colorimetric method of Vanillin-Hydrochloric Acid (Makkar and Becker, 1993) on 20 dominating fodder species, identified as such after calculating the RVI. The results from the CT should be approached carefully, since no liquid nitrogen was used during the sampling nor was it refrigerated later for the preservation of the samples.

\section{Determination of ruminal degradability and concentration of metabolizable energy}

After 48 hours, assays of ruminal degradability were performed in situ of the dry matter on 16 of the most dominating fodder species. The technique of nylon bag with a pore opening of $53 \mu \mathrm{m}$ (Ørskov et al., 1980) was used in two cows (430 kg of live weight) canulated in the rumen and fed with 20 $\mathrm{kg}$ of Pennisetum purpureum ( $c v$ Taiwan), $4 \mathrm{~kg}$ of Leucaena leucocephala and $1 \mathrm{~kg}$ of concentrate (13.5\% of PC). The metabolizable energy (ME) was estimated, using the in situ degradability of dry matter (Dis DM) with the following equation (Orskov et al., 1980):

$\operatorname{EM}(\mathrm{MJ} / \mathrm{kg})=(2.27563+0.1073) \times \mathrm{D} i \mathrm{MS}$

\section{Data analysis}

In order to describe the levels of dominance, the RVI of the herbaceous and woody strata of all the species (fodder and non-fodder) was estimated (Mueller-Dombois and Ellenberg, 1974). The values of abundance, frequency, coverage and DBH found in the production units were integrated into a single group of data for the FC, another for the SC and a last one for the HC. The fodder species with highest dominance were selected to subject them to chemical-nutritional analysis. 


\section{Análisis estadísticos}

Para determinar si la composición de especies forrajeras cambió entre las diferentes comunidades vegetales estudiadas se estimó su similitud a través del Coeficiente de Sorensen (Magurran, 1988) mediante el método de análisis de grupos pareados sin ponderar, usando la media aritmética (UPGMA), utilizando el Programa Estadístico Multivariado (MVSP, versión 3.1, 1985-2013, Kovach Computing Services) (Sørensen, 1948; Kovach, 2007). Se eligió la variable abundancia absoluta como indicador de proporción (Magurran, 1988) de especies forrajeras dentro de cada comunidad vegetal. Se realizaron análisis de varianza de la abundancia absoluta de especies forrajeras y de la fitomasa potencial, aplicando modelos factoriales de $2 \times 2$ (dos comunidades vegetales por dos épocas del año en leñosas) y $3 \times 2$ (tres comunidades vegetales por dos épocas del año en herbáceas). Se utilizó el programa SAS (Statistical Analysis System Inc. 2000; North Caroline; USA; versión 8.1.).

\section{Resultados y Discusión}

\section{Atributos de la vegetación y de las especies forrajeras}

Se registraron 1745 individuos, distribuidos en 154 especies, agrupadas en 49 familias (forrajeras y no forrajeras). Según el estimador de Chao 2 Mean, la curva de acumulación de especies no llegó a la asíntota (Figura 1); sin embargo, se obtuvo una representación de $85.5 \%$ de la riqueza esperada (180 especies).

La riqueza de especies forrajeras fue de 54, agrupadas en 21 familias, en contraste con las ocho forrajeras encontradas en el municipio Tzucacab, Yucatán (Zamora et al., 2009) y 35 forrajeras para bovinos en la Península de Yucatán (Flores y Bautista, 2012), indicando una alta riqueza de forrajeras en los sitios estudiados. La riqueza forrajera fue numéricamente mayor en época de lluvias, excepto en la CA (Cuadro 1), sugiriendo la presencia de especies con mayor resistencia a la sequía en este tipo de comunidad. La familia Fabaceae fue la más representada (Cuadro 2) y la más dominante (Cuadro 3 ), en coincidencia con Flores y Bautista (2012), Zamora et al. (2008) y Gutiérrez et al. (2012). Lo

\section{Statistical analysis}

To determine whether the composition of fodder species changed between the different vegetation communities studied, their similarity was estimated through the Sorensen Coefficient (Magurran, 1988) using the method of paired group analysis without bias, with the arithmetic mean (UPGMA), using the Statistical Multivatiate Program (MVSP, version 3.1, 1985-2013, Kovach Computing Services) (Sørensen, 1948; Kovach, 2007). The variable of absolute abundance was selected as an indicator of proportion (Magurran, 1988) of fodder species inside each plant community. Variance analyses were performed of the absolute abundance of fodder species and the potential phytomass, applying factorial models of $2 \times 2$ (two plant communities for two times of the year in woody) and $3 \times 2$ (three plant communities for two times of the year in herbaceous). The SAS software was used (Statistical Analysis System Inc. 2000; North Caroline; USA; version 8.1.).

\section{Results AND Discussion}

\section{Attributes of the vegetation and of the fodder species}

More than one thousand individuals (1745) were found, distributed in 154 species, grouped into 49 families (fodder and non-fodder). According to the Chao 2 Mean estimator, the accumulation curve of species did not reach the asymptote (Figure 1); however, a representation of $85.5 \%$ of the wealth expected (180 species) was obtained.

The wealth of fodder species was 54 , grouped into 21 families, in contrast with the eight fodder species found in the municipality of Tzucacab, Yucatán (Zamora et al., 2009) and 35 fodder species for bovines in the Yucatán Peninsula (Flores and Bautista, 2012), indicating a high wealth of fodder species in the sites studied. The fodder wealth was numerically higher in the rainy season, except in the SC (Table 1 ), suggesting the presence of species with highest resistance to drought in this type of community. The Fabaceae family was the most represented (Table 2) and the most dominant (Table 3), in agreement with Flores and Bautista (2012), Zamora et al. (2008) and Gutiérrez et al. (2012). This is explained because it is one of the most important families in the world 


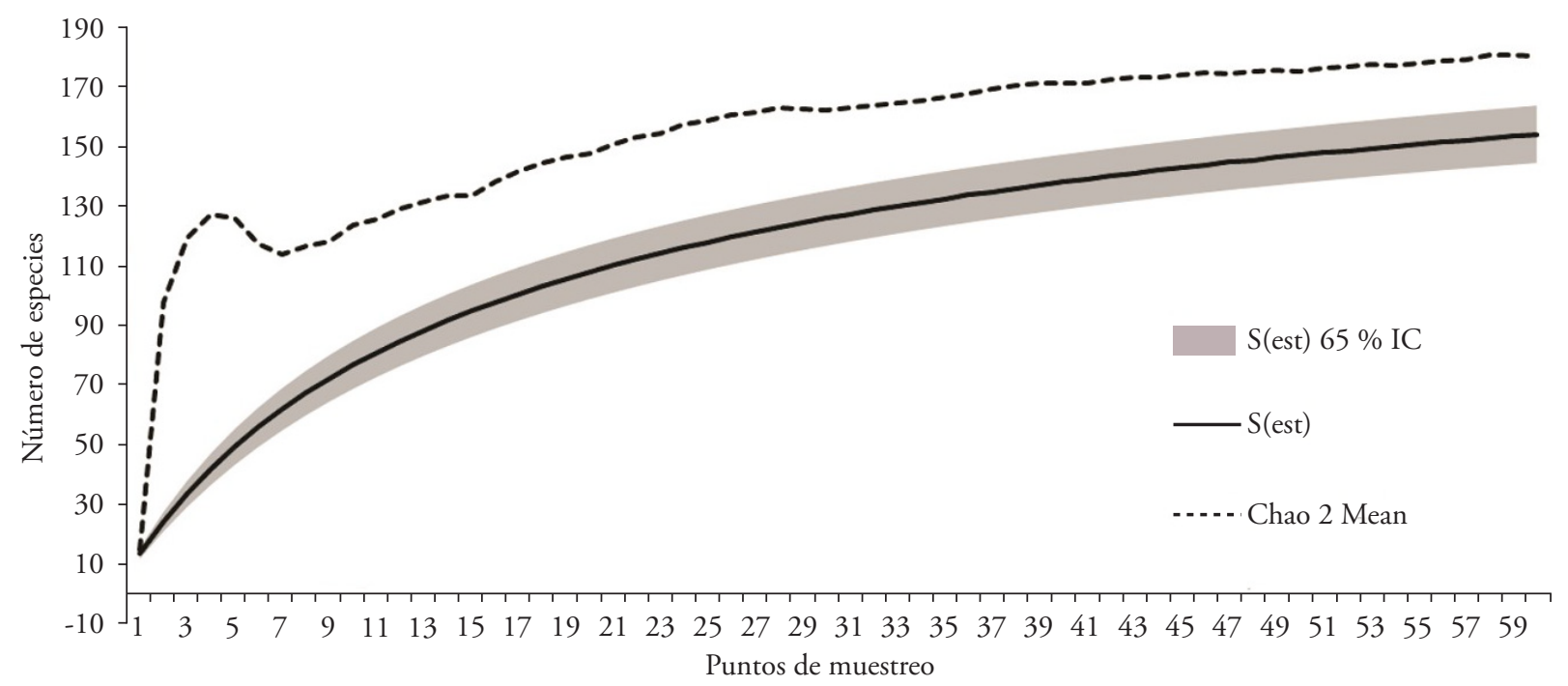

I.C.: intervalo de confianza, S (est): especies observadas. $*$ I.C.: interval of trust, S (est): species observed.

Figura 1. Curva de acumulación de especies Chao 2 Mean.

Figure 1. Accumulation curve of Chao 2 Mean species.

anterior se explica por ser una de las familias más importantes de la flora mundial y del trópico (Flores, 2001), por lo que ha sido considerada un forraje importante en la producción animal (NAS, 1979).

En cuanto al tipo de especies forrajeras y su dominancia en relación con el tipo de vegetación o tiempo de abandono (Cuadro 3) se observaron especies similares a las encontradas por Flores (2001) en la zona henequenera de Yucatán, con rangos de VIR relativamente similares en Hyptis suaveloens con (VIR $10.19 \%$ ), Piscidia piscipula (VIR $79.74 \%$ ) y Guazuma ulmifolia (VIR 25.02 \%) en sitios con dos, cinco y quince ańos de abandono respectivamente. Las forrajeras leńosas tuvieron la tendencia a ocupar los primeros lugares de importancia relativa (VIR) y las forrajeras herbáceas lugares más bajos, excepto en la Comunidad Herbácea, donde dominaron las for- flora and in the tropics (Flores, 2001), which is why it has been considered an important fodder in animal production (NAS, 1979).

In terms of the type of fodder species and their dominance in relation to the type of vegetation or time of abandonment (Table 3), similar species to those found by Flores (2001) were observed in the henequen zone of Yucatán, with ranges of RVI relatively similar in Hyptis suaveloens (RVI $10.19 \%$ ), Piscidia piscipula (RVI $79.74 \%$ ) and Guazuma ulmifolia (RVI $25.02 \%$ ) in sites with two, five and fifteen years of abandonment, respectively. The woody fodder species had the tendency of occupying the first places of relative importance (RVI) and the herbaceous fodders lower places, except in the Herbaceous Community, where the herbaceous fodder species in the medium sub-deciduous

Cuadro 1. Riqueza de especies forrajeras por comunidad vegetal, estrato y época del ańo en una selva mediana subcaducifolia secundaria.

Table 1. Wealth of fodder species per plant community, stratum and season of the year in a medium sub-deciduous secondary rainforest.

\begin{tabular}{|c|c|c|c|c|c|c|}
\hline \multirow{2}{*}{ Estrato vegetal } & \multicolumn{2}{|c|}{ Comunidad forestal } & \multicolumn{2}{|c|}{ Comundad arbustiva } & \multicolumn{2}{|c|}{ Comunidad herbácea } \\
\hline & Lluvias & Secas & Lluvias & Secas & Lluvias & Secas \\
\hline Estrato leńoso & 21 & 16 & 16 & 16 & - & - \\
\hline Estrato herbáceo & 8 & 5 & 6 & 6 & 18 & 6 \\
\hline
\end{tabular}


Cuadro 2. Especies consideradas como forrajeras en sitios de pastoreo de bovinos en selva mediana subcaducifolia secundaria. Table 2. Species considered as fodder in bovine grazing sites in a medium sub-deciduous secondary rainforest.

\begin{tabular}{|c|c|c|c|}
\hline Familia & $\begin{array}{l}\text { Número } \\
\text { de especies }\end{array}$ & Especie & $\begin{array}{l}\text { Fuente } \\
\text { bibliográfica }\end{array}$ \\
\hline Amaranthaceae & 1 & Celosia virgata Jaq. & CICY, 2010 \\
\hline \multirow[t]{2}{*}{ Arecaceae } & 2 & Acrocomia aculeata (Jacq.) Lodd. ex Mart. & Andrade et al., 2008 \\
\hline & & Sabal yapa C. Wright Becc. & Flores y Bautista, 2012 \\
\hline \multirow[t]{2}{*}{ Asteraceae } & 2 & Melanthera angustifolia A. Rich. & CICY, 2010 \\
\hline & & Viguiera dentata (Cav.) Spreng. var. dentata & González et al., 2014 \\
\hline \multirow[t]{2}{*}{ Boraginaceae } & 2 & Cordia globosa (Jacq.) Kunth & Romero y Duarte, 2012 \\
\hline & & Ehretia tinifolia L. & Ayala et al., 2006 \\
\hline Burseraceae & 1 & Bursera simaruba (L.) Sarg. & Flores y Bautista, 2012 \\
\hline Convolvulaceae & 1 & Merremia aegyptia (L.) Urb. & Flores y Bautista, 2012 \\
\hline \multirow[t]{2}{*}{ Cyperaceae Juss. } & 2 & Cyperus haspan $\mathrm{L}$. & CICY, 2010 \\
\hline & & Cyperus odoratus L. & CICY, 2010 \\
\hline Euphorbiaceae & 1 & Cnidoscolus aconitifolius (Mill.) I.M. Johnst. & González et al., 2014 \\
\hline \multirow[t]{4}{*}{ Fabaceae } & 20 & Acacia collinsii Saff. & Flores y Bautista, 2012 \\
\hline & & Acacia cornigera (L.) Willd. & Vásquez et al., 2012 \\
\hline & & Acacia farnesiana (L.) Willd. & Ayala et al., 2006 \\
\hline & & Acacia pennatual (Schltdl. \& Cham.) Benth. & Ayala et al., 2006, Flores y Bautista, 2012 \\
\hline \multirow[t]{15}{*}{ Fabaceae } & & Baubinia divaricata $\mathrm{L}$. & Jackson, 1996 \\
\hline & & Bauhinia ungulata L. & Pinto et al., 2004 \\
\hline & & Chloroleucon mangense (Jacq.) Britton \& Rose & CICY. 2010 \\
\hline & & Dalbergia glabra (Mill.) Standl. & Sosa et al., 2000 \\
\hline & & Desmodium incanum DC. & Sosa et al., 2000, Jackson, 1996 \\
\hline & & Desmodium tortuosum (Sw.) DC. & Sosa et al., 2000 \\
\hline & & Enterolobium cyclocarpum Griseb. & Rico et al., 1991 \\
\hline & & $\begin{array}{l}\text { Leucaena leucocephala (Lam.) de Wit. ssp. } \\
\text { Leucocephala }\end{array}$ & Flores y Bautista, 2012 \\
\hline & & Lonchocarpus punctatus Kunth. & Achan et al., 2011 \\
\hline & & Lonchocarpus rugosus Benth. & Cab et al., 2015 \\
\hline & & Mimosa pudica L. & ECOCROP, 2007 \\
\hline & & Mucuna pruriens (L.) DC. & Adjorlolo et al., 2004 \\
\hline & & Piscidia piscipula (L.) Sarg. & Ayala et al., 2006, Flores y Bautista 2012 \\
\hline & & Pithecellobium dulce (Roxb.) Benth. & Flores y Bautista, 2012 \\
\hline & & Senna uniflora (Mill.) H.S. Irwin \& Barneby. & Jackson, 1996 \\
\hline \multirow[t]{3}{*}{ Lamiaceae } & 3 & Callicarpa acuminata Kunth. & Mizrahi et al., 1997 \\
\hline & & Hyptis suaveolens (L.) Poit. & Flores y Bautista, 2012 \\
\hline & & Vitex gaumeri Greenm. & Ayala et al., 2006, Flores y Bautista 2012 \\
\hline Malpighiaceae & 1 & Byrsonima crassifolia (L.) Kunth. & Rico et al., 1991 \\
\hline \multirow[t]{3}{*}{ Malvaceae Juss. } & 3 & Guazuma ulmifolia Lam. & Flores y Bautista 2012 \\
\hline & & Malvaviscus arboreus Cav. & Velázquez et al., 2010 \\
\hline & & Sida acuta Burm. F. & Vásquez et al., 2012 \\
\hline Marantaceae & 1 & Maranta arundinacea f. sylvestris Matuda. & ECOCROP 2007 \\
\hline Nyctaginaceae & 1 & Pisonia aculeata $\mathrm{L}$. & Velázquez et al., 2011 \\
\hline Picramniaceae & 1 & Alvaradoa amorphoides Liebm. ssp. Amorphoides & Sosa et al., 2000 \\
\hline \multirow[t]{6}{*}{ Poaceae } & 6 & Ischaemum rugosum Salisb. & Sadi et al., 2015 \\
\hline & & Lasiacis ruscifolia (Kunth) Hitchc. var. ruscifolia & CICY, 2010 \\
\hline & & Oplismenus burmannii (Retz.) P. Beauv. & CICY, 2010 \\
\hline & & Panicum maximum Jacq. & Castellón y Elías, 2015 \\
\hline & & Paspalum plicatulum Michaux & Vásquez et al., 2012 \\
\hline & & Paspalum langei ( E. Fourn) Nash & CICY, 2010 \\
\hline \multirow[t]{3}{*}{ Rubiaceae } & 3 & Guettarda combsii Urb. & Sosa et al., 2000 \\
\hline & & Hamelia patens Jacq. & Sosa et al., 2000 \\
\hline & & Psychotria nervosa Sw. & López et al., 2008 \\
\hline
\end{tabular}


Cuadro 2. Continuación.

Table 2. Continuation.

\begin{tabular}{lcll}
\hline \multicolumn{1}{c}{ Familia } & $\begin{array}{c}\text { Número } \\
\text { de especies }\end{array}$ & \multicolumn{1}{c}{ Especie } & \multicolumn{1}{c}{$\begin{array}{c}\text { Fuente } \\
\text { bibliográfica }\end{array}$} \\
\hline Sapotaceae & 1 & Chrysophyllum mexicanum Brandegee in Standl. & Sosa et al., 2000 \\
Solanaceae & 1 & Solanum hirtum Vahl. & Flores y Bautista, 2012 \\
Violaceae & 1 & Hybanthus yucatanensis Millsp. & Mizrahi et al., 1997 \\
\hline
\end{tabular}

rajeras herbáceas en la selva mediana subcaducifolia secundaria (Cuadro 3). La dominancia de forrajeras perennes podría favorecer la permanencia de alimento potencial en la época crítica del año, especialmente especies como Acacia pennatula, Celosia virgata, Guazuma ulmifolia, Hybanthus yucatanensis y Piscidia piscipula (CICY, 2010), en tanto que en la CH dominaron principalmente las Poaceas, por ser un estadio joven de sucesión con poca tolerancia a la sombra y ser resistentes al pastoreo (Gleen-Lewin et al., 1992; Villegas et al., 2001). Por otro lado, la similitud entre las comunidades Forestal y Arbustiva fue 0.54 en lluvias y 0.47 en secas; en la Comunidad Herbácea en lluvias y en secas fue 0.36 y en la Comunidad Her- secondary rainforest dominated (Table 3). The dominance of perennial fodder species could favor the permanence of potential food in the critical time of the year, especially species such as Acacia pennatula, Celosia virgata, Guazuma ulmifolia, Hybanthus yucatanensis and Piscidia piscipula (CICY, 2010), while in the HC the Poaceas dominated primarily, because it is a young stage of succession with low tolerance to shade and resistant to grazing (Gleen-Lewin et al., 1992; Villegas et al., 2001). On the other hand, the similarity between the Forest and Shrub communities was 0.54 in rain season and 0.47 in dry season; in the Herb Community in rain and dry seasons it was 0.36, and in Herb Community

Cuadro 3. Valores de importancia relativa de las especies forrajeras en las diferentes comunidades vegetales en la selva mediana subcaducifolia secundaria en lluvias y secas.

Table 3. Values of relative importance of the fodder species in the different plant communities in the medium sub-deciduous secondary rainforest in the rain and dry seasons.

\begin{tabular}{|c|c|c|c|c|c|c|c|c|}
\hline \multirow{2}{*}{$\begin{array}{l}\text { Comunidad } \\
\text { forestal }\end{array}$} & \multirow[b]{2}{*}{ Familia } & \multicolumn{3}{|c|}{ Época de lluvias de 2013} & \multirow[b]{2}{*}{ Familia } & \multicolumn{3}{|c|}{ Época de secas de 2014} \\
\hline & & Especie & $\begin{array}{c}\text { Nivel } \\
\text { VIR }\end{array}$ & $\begin{array}{c}\text { VIR } \\
\%\end{array}$ & & Especie & $\begin{array}{l}\text { Nivel } \\
\text { VIR }\end{array}$ & $\begin{array}{c}\text { VIR } \\
\%\end{array}$ \\
\hline \multirow[t]{2}{*}{ Estrato leñoso. } & Arecaceae & Sabal yapa & 1 & 39.45 & Solanaceae & Solanum hirtum & 1 & 36.61 \\
\hline & Fabaceae & Bauhinia divaricata & 2 & 38.34 & Violaceae & Hybanthus yucatanensis & 2 & 24.03 \\
\hline \multirow{3}{*}{$\begin{array}{l}\text { Entre } 1 \text { y } 4 \mathrm{~m} \text { de } \\
\text { alto promedio }\end{array}$} & Violaceae & Hybanthus yucatanensis & 3 & 34.29 & Malvaceae & Guazuma ulmifolia & 5 & 19.15 \\
\hline & Fabaceae & Piscidia piscipula & 4 & 29.56 & Fabaceae & Piscidia piscipula & 6 & 17.15 \\
\hline & Poaceae & Lasciasis ruscifolia & 1 & 44.87 & Amaranthaceae & Celosia virgata & 2 & 18.6 \\
\hline \multirow{3}{*}{ Estrato herbáceo } & Amaranthaceae & Celosia virgata & 2 & 45.18 & Poaceae & Lasiacis divaricata & 7 & 14.44 \\
\hline & Fabaceae & Mucuna pruriens & 7 & 18.47 & Fabaceae & Dalbergia glabra & 8 & 13.39 \\
\hline & Marantaceae & Maranta arundinicea & 11 & 9.79 & Malvaceae & Sida acuta & 15 & 7.97 \\
\hline \multirow{5}{*}{$\begin{array}{l}\text { Estratovegetal leñoso } \\
\text { Entre } 0.5 \text { y } 2 \mathrm{~m} \text { de } \\
\text { alto promedio }\end{array}$} & Fabaceae & Baubinia ungulata & 1 & 111.76 & Fabaceae & Baubinia ungulata & 1 & 26.5 \\
\hline & Fabaceae & Acacia pennatula & 2 & 34.57 & Arecaceae & Sabal yapa & 2 & 24.65 \\
\hline & Fabaceae & Senna uniflora & 3 & 24.94 & Fabaceae & Acacia collinsii & 3 & 22.27 \\
\hline & Fabaceae & Piscidia piscipula & 4 & 21.62 & Fabaceae & Acacia pennatula & 4 & 20.43 \\
\hline & Lamiaceae & Hyptis suaveolens & 1 & 46.87 & Poaceae & Ischaemum rugosum & 1 & 54.12 \\
\hline \multirow{3}{*}{$\begin{array}{l}\text { Estrato vegetal } \\
\text { herbáceo }\end{array}$} & Poaceae & Ischaemum rugosum & 2 & 45.5 & Poaceae & Panicum maximum & 5 & 19.73 \\
\hline & Poaceae & Lasciasis ruscifolia & 12 & 7.29 & Fabaceae & Desmodium incanum & 6 & 19.56 \\
\hline & Poaceae & Paspalum langei & 15 & 5.22 & Malvaceae & Sida acuta & 14 & 5.2 \\
\hline \multirow{3}{*}{$\begin{array}{l}\text { Comunidad } \\
\text { herbácea }\end{array}$} & Malvaceae & Sida acuta & 3 & 19.68 & Poaceae & Panicummaximum & 2 & 24.03 \\
\hline & Fabaceae & Mucuna pruriens & 4 & 16.97 & Asteraceae & Melanthera angustifolia & 4 & 13.93 \\
\hline & Marantaceae & Maranta arundinacea & 5 & 13.22 & Fabaceae & Desmodium incanum & 13 & 8.26 \\
\hline
\end{tabular}

VIR: índice de valor de importancia relativa en escala de 1 a 300. RVI: Index of value of relative importance in a scale of 1 to 300. 
bácea con las comunidades Forestal y Arbustiva fue 0.27 (Figura 2), lo que indicó que el tipo de especies cambió entre las comunidades vegetales, ofreciendo gran variedad de especies.

Por otro lado, se encontró interacción por efecto de época y comunidad en la abundancia de especies forrajeras leñosas $(p=0.01)$, siendo mayor en lluvias en la Comunidad Forestal $(\mathrm{p}<0.0001)$ y en secas en la Comunidad Arbustiva $(\mathrm{p}=0.0019)$ (Cuadro 4). En cuanto a la abundancia en la Comunidad Forestal, se vio más favorecida en especies leñosas en lluvias y la Comunidad Arbustiva se vio menos afectada en secas, haciendo de la CA un reservorio de alimento en la época crítica de sequía. La varianza elevada en la abundancia de herbáceas en la CF se explica por la poca tolerancia de este estrato a la sombra (GleenLewin et al.,, 1992), por lo que distintas condiciones de luz creadas por el estrato leñoso pueden variar dentro del mismo sitio, originando constantes diferencias en su abundancia. En este sentido es necesario conocer la selectividad y preferencias del ganado al seleccionar su dieta para entender cómo aprovecha la riqueza nutricional de la vegetación secundaria.

\section{Fitomasa potencial}

La fitomasa potencial de la vegetación secundaria fue $3272 \mathrm{~kg}$ MS/ha en lluvias y $1454 \mathrm{~kg}$ MS/ha en secas a través de todos los estratos y comunidades, lo que coincide con las cantidades de forraje disponible reportado por CICC (2009) para la Península de Yucatán, siendo congruente la carga animal utilizada en los sitios de estudio, con la capacidad de carga animal

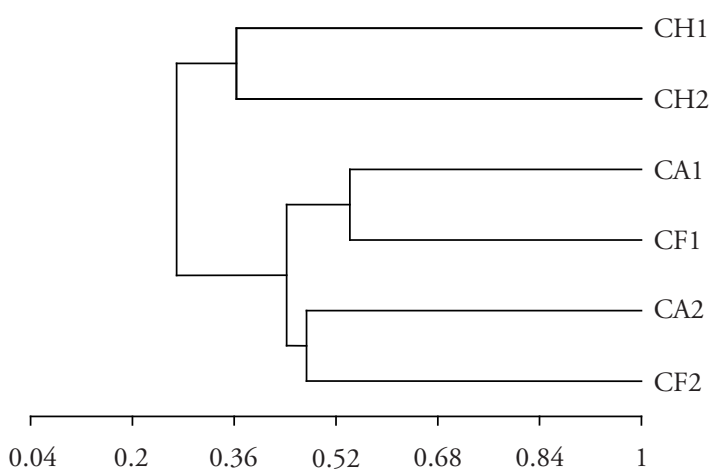

$\mathrm{CH} 1$ : Comunidad Herbácea en lluvias; CH2: Comunidad Herbácea en secas. CA1: Comunidad Arbustiva en lluvias; CA2: Comunidad Arbustiva en secas. CF1: Comunidad Forestal en lluvias; CF2: Comunidad Forestal en secas. $* \mathrm{CH} 1$ : Herbaceous community in rain season; $\mathrm{CH} 2$ : Herbaceous community in dry season. CA1: Shrub community in rain season; CA2: Shrub community in dry season. CF1: Forest community in rain season; CF2: Forest community in dry season.

Figura 2. Dendrograma de similitud del Coeficiente de Sorensen de las especies consideradas como forrajeras en la selva mediana subcaducifolia.

Figure 2. Dendrogram of similarity from the Sorensen Coefficient of the species considered as fodder in the sub-deciduous medium rainforest.

with the Forest and Shrub communities it was 0.27 (Figure 2), which indicated that the type of species changed between plant communities, offering a great variety of species.

On the other hand, interaction was found from the effect of season and community in the abundance of woody fodder species $(p=0.01)$, with it being

Cuadro 4. Abundancia absoluta de especies forrajeras en función de la comunidad vegetal y época del ańo en la selva mediana subcaducifolia secundaria.

Table 4. Absolute abundance of fodder species in function of the plant community and season of the year in the medium subdeciduous secondary rainforest.

\begin{tabular}{|c|c|c|c|c|c|c|c|c|c|}
\hline \multirow{2}{*}{$\begin{array}{l}\text { Comunidad } \\
\text { vegetal }\end{array}$} & \multicolumn{2}{|c|}{ Comunidad forestal } & \multicolumn{2}{|c|}{ Comunidad arbórea } & \multicolumn{2}{|c|}{ Comunidad herbácea } & \multirow{2}{*}{$\begin{array}{c}\text { Efecto } \\
\text { época } \\
\text { (p) }\end{array}$} & \multirow{2}{*}{$\begin{array}{c}\text { Efecto } \\
\text { comunidad } \\
\text { (p) }\end{array}$} & \multirow{2}{*}{$\begin{array}{c}\text { Efecto } \\
\text { interacció } \\
\text { (p) }\end{array}$} \\
\hline & Lluvias & Secas & Lluvias & Secas & Lluvias & Secas & & & \\
\hline \multicolumn{10}{|l|}{ Estrato leńoso } \\
\hline $\begin{array}{l}\text { Abundancia } \\
\text { absoluta }\end{array}$ & $52.8 \mathrm{a} \pm 11.4$ & $14.80 \mathrm{~d} \pm 3.09$ & $29.8 b \pm 11.81$ & $16.8 \mathrm{c} \pm 2.87$ & - & - & $<0.0001$ & 0.03 & 0.01 \\
\hline \multicolumn{10}{|l|}{ Estrato herbáceo } \\
\hline $\begin{array}{l}\text { Abundancia } \\
\text { absoluta }\end{array}$ & $12.0 \mathrm{~b} \pm 12.59$ & $4.5 c \pm 9.0$ & $40 \mathrm{a} \pm 19.50$ & $20.0 \mathrm{~b} \pm 10.70$ & $36 a \pm 6.70$ & $13 b \pm 7.63$ & 0.0008 & 0.001 & 0.30 \\
\hline
\end{tabular}

p: valor de la significancia; \pm : Desviación estándar. En los valores que no comparten literal, se encontró diferencia significativa ( $\mathrm{p} \leq 0.05$ ). * p: value of significance; \pm : standard deviation. In the values that don't share literal, significant difference was found $(\mathrm{p} \leq 0.05)$. 
indicados para la región (CICC, 2009). En el estrato leñoso forrajero hubo mayor fitomasa potencial en la Comunidad Arbórea en lluvias (2 030 741 kg MS/ ha) explicado por el efecto de la época $(\mathrm{p}<0.0001)$. En el estrato herbáceo se encontró mayor fitomasa potencial en la Comunidad Herbácea $(3977 \pm 2299$ $\mathrm{kg}$ MS/ha en lluvias y $2451 \pm 3336 \mathrm{~kg}$ MS/ha en secas) explicado por el efecto de la comunidad $(p=0.011)$. La varianza elevada en la fitomasa potencial se explica por la presencia de afloraciones de roca donde no se encontró vegetación; característico de los Leptosoles (Flores y Bautista, 2005). El aporte de fitomasa potencial de la $\mathrm{CH}$, debido a la presencia de herbáceas y gramíneas, podría ser un elemento clave para complementar la fuente de alimento para el ganado en la selva subtropical secundaria; ya que las gramíneas han sido asociadas tradicionalmente a la ganadería por ser una fuente importante de materia seca, con capacidad de rebrote y resistencia al pastoreo que pueden tener buena calidad nutritiva (Villegas et al., 2001). La selva mediana subcaducifolia se caracteriza por una defoliación entre 50 y $75 \%$ (Flores y Espejel, 1994), indicando que la presencia de fitomasa potencial en secas podría significar un recurso alimenticio estratégico para la supervivencia del ganado, además de la hojarasca y vainas (Pettit et al., 2011). Si bien la ganadería tradicional en el sur de Yucatán se basa en alimentación con pastos de temporal (Osorio y Marfil, 1999); posiblemente la presencia de áreas en etapas sucesionales jóvenes (con gramíneas), intermedias (con leñosas) y maduras (con árboles desarrollados); podría estar vinculado con prácticas de pastoreo en época de lluvias y secas. Ya que no se cuenta con informes en los sitos de estudio de fitomasa potencial, los resultados obtenidos son muy importantes para lograr un mejor aprovechamiento del recurso forrajero en éstos sistemas de producción.

\section{Composición químico nutricional, degradabilidad ruminal y concentración de energía metabolizable de las especies forrajeras}

La composición químico-nutricional de las especies forrajeras dominantes analizadas varió entre 35 y $77 \%$ en su contenido de FDN; de 5 a $27 \%$ de PC; de no detectables, a $12.75 \%$ de TC; de 49 a $94.75 \%$, de DisMS a las 48 h; y de 7.57 a 12.43, de MJ de EM, destacando Senna uniflora, con 94.66 \% higher in the rain season of the Forest Community $(p<0.0001)$ and in the dry season in the Shrub Community $(p=0.0019)$ (Table 4$)$. In terms of the abundance in the Forest Community, it was favored in woody species in the rain season and the Shrub Community was less affected in the dry season, making the $\mathrm{SC}$ a food reservoir in the critical drought season. The high variance in the abundance of herb species in the FC was explained by the low tolerance of this stratum to the shade (Gleen-Lewin et al.,, 1992), which is why different light conditions created by the woody stratum can vary within the same site, originating constant differences in their abundance. In this sense it is necessary to understand the selectivity and preferences of the livestock when selecting their diet to understand how the nutritional wealth of the secondary vegetation is exploited.

\section{Potential phytomass}

The potential phytomass of the secondary vegetation was $3272 \mathrm{~kg} \mathrm{DM} / \mathrm{ha}$ in the rainy season and $1454 \mathrm{~kg} \mathrm{DM} / \mathrm{ha}$ in the dry season throughout all the strata and communities, which agrees with the amounts of fodder available reported by CICC (2009) for the Yucatán Peninsula, with the animal load used in the study sites being consistent with the capacity of animal load indicated for the region (CICC, 2009). In the woody fodder stratum there was higher potential phytomass in the Forest Community in the rain season $(2030 \pm 741 \mathrm{~kg} \mathrm{DM} / \mathrm{ha})$ explained by the impact of the season $(\mathrm{p}<0.0001)$. In the herbaceous stratum a higher phytomass potential was found in the Herb Community $(3977 \pm 2299 \mathrm{~kg} \mathrm{DM} / \mathrm{ha}$ in the rain season and $2451 \pm 3336 \mathrm{~kg} \mathrm{DM} / \mathrm{ha}$ in the dry season) explained by the effect of the community $(\mathrm{p}=0.011)$. The high variance in the potential phytomass is explained by the presence of rock outcrops where no vegetation was found, characteristic of Leptosols (Flores and Bautista, 2005). The potential phytomass contribution of the $\mathrm{HC}$, due to the presence of herbs and grasses, could be a key element to complement the source of food for the cattle in the secondary subtropical rainforest, since grasses have been traditionally associated to livestock production because they are an important source of dry material, with regrowth capacity and resistance to grazing that may have good nutritional quality (Villegas et al., 2001). The medium sub-deciduous rainforest is characterized by a defoliation of between 50 and $75 \%$ 
Cuadro 5. Valores de la composición químico-nutritiva, degradabilidad ruminal y concentración de energía metabolizable de las especies forrajeras dominantes de la selva mediana subcaducifolia secundaria en época de lluvias 2013.

Table 5. Values of the chemical-nutritional composition, ruminal degradability, and concentration of metabolizable energy of the dominant fodder species in the medium sub-deciduous secondary rainforest during the rain season 2013.

\begin{tabular}{|c|c|c|c|c|c|}
\hline Espacie forrajera & FDN \% & PC \% & TC \% & DisMS \% & $\mathrm{EM}(\mathrm{MJ} \mathrm{kg} / \mathrm{MS})$ \\
\hline Acacia pennatula & 41.45 & 18.26 & 3.79 & 77.560 & 10.600 \\
\hline Bauhinia divaricata & 46.49 & 12.78 & 12.75 & 65.930 & 9.350 \\
\hline Bauhinia ungulata & 57.23 & 11.16 & ND & 49.380 & 7.570 \\
\hline Celosia virgata & 46.34 & 19.6 & ND & 77.780 & 10.620 \\
\hline Desmodium incanum & 46.38 & 17.96 & ND & 76.200 & 10.450 \\
\hline Guazuma ulmifolia & 55.70 & 12.77 & ND & 77.460 & 10.590 \\
\hline Hybanthus yucatanensis & 37.58 & 23.51 & ND & 89.030 & 11.830 \\
\hline Hyptis suaveolens & 58.05 & 13.17 & 0.11 & 59.835 & 8.695 \\
\hline Ischaemum rugosum & 77.02 & 7.08 & ND & 62.320 & 8.950 \\
\hline Lasciasis ruscifolia & 49.18 & 14.79 & ND & 83.430 & 11.230 \\
\hline Maranta arundinacea & 62.53 & 9.81 & ND & 70.410 & 9.830 \\
\hline Melanthera angustifolia & 35.15 & 14.95 & 0.24 & - & - \\
\hline Mucuna pruriens & 43.44 & 27.35 & ND & 86.115 & 11.520 \\
\hline Panicum máximum & 69.94 & 6.26 & 0.25 & - & - \\
\hline Paspalum langei & 70.09 & 6.70 & ND & 55.570 & 8.230 \\
\hline Piscidia piscipula & 41.74 & 15.33 & 0.69 & 52.570 & 7.910 \\
\hline Sabal yapa & 53.38 & 11.46 & ND & 75.340 & 10.360 \\
\hline Senna uniflora & 55.13 & 12.06 & 8.74 & 94.660 & 12.430 \\
\hline Sida acuta & 43.68 & 15.24 & 2.87 & - & - \\
\hline Solanum hirtum & 54.44 & 5.29 & 0.75 & - & - \\
\hline
\end{tabular}

FDN: Fibra Detergente Neutra; PC: Proteína Curda; TC: Taninos Condensados; DisMS: Degradabilidad in situ de la materia seca a las 48 h; EM (MJ kg/MS): Concentración de energía metabolizable expresada en mega joules por kg de materia seca ND: No determinado. * FDN: Neutral Detergent Fiber; PC: Raw Protein; TC: Condensed Tannins; DisMS: Degradability in situ of the dry matter at 48 h; EM (MJ kg/MS): Metabolizable energy concentration expressed in mega joules per kg of dry matter. ND: Not determined.

en DisMS a las 48 h (Cuadro 5). Los rangos de valores nutricionales aquí encontrados coincidieron con los encontrados en otros estudios (Ayala et al., 2006; Palma et al., 2011), especialmente en contenidos de proteína cruda arriba de $12 \%$ en especies leñosas y porcentajes de DisMS alrededor de $70 \%$. El contenido elevado de FDN de las Poaceas (arriba del $69 \%$ ) es característica de los pastos tropicales, a excepción de Lasciasis ruscifolia (Cuadro 5), cuya característica perenne y su elevada dominancia podrían hacerla estratégica en la época de secas, en tanto que las concentraciones de nutrientes y compuestos secundarios fueron muy diversos, lo que a su vez definieron digestibilidades y concentraciones de energía metabolizable en un amplio rango de variación. Esto también ha sido encontrado en otros estudios de vegetación diversa en comunidades sujetas al pastoreo (Velázquez et al., 2010; Flores y Bautista, 2012).

Con base en la dominancia de especies forrajeras reflejada en el VIR (Cuadro 3) y con los valores de la composición químico-nutricional obtenidos
(Flores and Espejel, 1994), indicating that the presence of potential phytomass in the dry season could mean a strategic dietary resource for the survival of the cattle, in addition to the fallen leaves and husks (Pettit et al., 2011). Although traditional livestock production in the south of Yucatán is based on feeding with rainfed grasses (Osorio and Marfil, 1999), possibly the presence of areas in successional young stages (with grasses), intermediate (with woody), and mature (with developed trees), could be linked to grazing practices in the rainy and dry seasons. Since there are no reports available in the study sites of potential phytomass, the results obtained are very important to achieve a better exploitation of the fodder resource in these production systems.

\section{Chemical-nutritional composition, ruminal degradability and metabolizable energy concentration of the fodder species}

The chemical-nutritional composition of the dominant fodder species analyzed varied between 35 
(Cuadro 5) se observó una tendencia en los valores de las especies de la CF que sugiere una oferta significativa de energía, debido al menor contenido de FDN, mayor DisMS y concentración de energía metabolizable, que implica un mayor aporte nutricional; aunque esta comunidad vegetal oferta menor cantidad de fitomasa potencial podría ser complementaria con el aporte de materia seca de la comunidad herbácea. Es importante señalar que para el aprovechamiento de las especies forrajeras arbóreas deben estar disponibles para el animal, o bien, destinarse como forraje de corte. Por otro lado, las especies con bajas concentraciones de FDN, elevadas Dis MS y concentración de EM podrían promover un mayor consumo voluntario (Dulphy y Demarquilly, 1994) y una tasa de pasaje más rápida (Ku et al., 1999), lo que podría representar una posible fuente de energía de rápida disponibilidad ruminal que permita maximizar la síntesis de proteína microbiana en el rumen, así como incrementar el aporte de nitrógeno microbiano al intestino delgado (Sauvant y Van Milgen, 1995), en tanto que la presencia de metabolitos secundarios en las plantas evaluadas podrían inducir a la mitigación en la producción de metano entérico al modificar las poblaciones microbianas en el rumen y, en consecuencia, modificar los productos de la fermentación (ácidos acético, propiónico y butírico) de los carbohidratos del rumen (Gerber et al., 2013), además del efecto nematicida, y que contribuirían a disminuir la carga de parásitos intestinales (Hoste et al., 2006; Mueller, 2006). Las especies forrajeras presentes, claramente diferenciadas por tipo de comunidad, podrían representar una oferta de alimento para el ganado bovino con diferentes características nutricionales que podrían complementarse a lo largo del año para una mejor distribución de la disponibilidad de forraje.

De esta manera, el potencial nutritivo de la vegetación secundaria antes descrito constituye un potencial de uso del pastoreo en este tipo de comunidades vegetales. El evitar el desmonte para inducir monocultivo de pasturas mejoradas al promover este pastoreo de la vegetación natural además de proveer con forraje complementario en épocas críticas permite que su estructura y diversidad de especies fomente una mayor conectividad entre fragmentos de vegetación primaria; la presencia misma de la vegetación secundaria optimiza servicios ambientales como la fijación de nitrógeno, la solubilidad del fósforo y mejorar la actividad biológica del suelo y ofrece hábitat para la fauna silvestre (Mur- and $77 \%$ in their NDF content; 5 to $27 \%$ of RP; non-detectable, at $12.75 \%$ of CT; from 49 to $94.75 \%$ of $\mathrm{D} i \mathrm{SDM}$ at $48 \mathrm{~h}$; and from 7.57 to 12.43 , MJ of ME, with Senna uniflora standing out, with $94.66 \%$ in DisDM at $48 \mathrm{~h}$ (Table 5). The ranges of nutritional values found here agreed with those found in other studies (Ayala et al., 2006; Palma et al., 2011), especially in contents of raw protein above $12 \%$ in woody species and percentages of Dis DM around $70 \%$. The high content of NDF in Poaceas (over $69 \%$ ) is characteristic of tropical grasses, except Lasciasis ruscifolia (Table 5), whose perennial characteristic and high dominance could make it strategic during the dry season, while the concentrations of nutrients and secondary compounds was quite diverse, which in turn defined digestibilities and metabolizable energy concentrations in a broad range of variation. This has also been found in other studies of diverse vegetation in communities subject to grazing (Velázquez et al., 2010; Flores y Bautista, 2012).

Based on the dominance of fodder species reflected in the RVI (Table 3) and the values of chemical-nutritional composition obtained (Table 5 ), a trend was observed in the values of the species of the FC that suggests a significant offer of energy, due to the lower content of NDF, higher Dis DM and concentration of metabolizable energy, which implies a higher nutritional contribution; although this plant community offers a lower amount of potential phytomass, it could be complementary to the contribution of dry matter of the herbaceous community. It is important to point out that for the exploitation of tree fodder species, they should be available for the animal, or else, be destined to fodder for cutting. On the other hand, the species with low concentrations of NDF, high DisDM and $\mathrm{ME}$ concentration could promote a higher voluntary consumption (Dulphy and Demarquilly, 1994) and a faster passage rate (Ku et al., 1999), which could represent a possible source of energy of fast ruminal availability that allows maximizing the microbial protein synthesis in the rumen, as well as increasing the contribution of microbial nitrogen to the small intestine (Sauvant and Van Milgen, 1995), while the presence of secondary metabolites in the plants evaluated could induce mitigation in the production of enteric methane when modifying the microbial populations in the rumen and, as consequence, modifying the products of fermentation (acetic, propionic and butyric acid) of rumen carbohydrates 
gueitio et al., 2008; 2011).

\section{Conclusiones}

Los diferentes estados sucesionales en la vegetación de la selva mediana subcaducifolia influyeron en la calidad y cantidad de alimento potencial para el ganado bovino.

Los estados sucesionales con mayor tiempo de abandono presentaron mejor calidad nutricional, medida a través de la degradabilidad ruminal y concentración de energía metabolizable que se complementan en cantidad de fitomasa potencial con los estados sucesionales más jóvenes donde dominan las Poaceas.

La vegetación de los estados intermedios de sucesión en secas puede ser estratégica para la supervivencia del ganado debido a la mayor abundancia de especies forrajeras resistentes a la sequía, por lo que la vegetación secundaria ofrece alimento suficiente y de alta calidad en los diferentes estados sucesionales en el trópico subhúmedo, con cargas animales ajustadas para el rendimiento de la fitomasa potencial.

\section{Agradecimientos}

Se agradece al Consejo Nacional de Ciencia y Tecnología por la beca para doctorado 169443/169443, al Programa de Apoyo a Proyectos de Investigación e Innovación Tecnológica (PAPIIT IT101813, IV200715) de la Universidad Nacional Autónoma de México por el financiamiento a esta investigación. Al Campus de Ciencias Biológicas y Agropecuarias, así como al Rancho Hobonil de la Universidad Autónoma de Yucatán por las facilidades otorgadas. También se agradece a Ignacio Alvarado, Rigoberto Ek por facilitar el espacio para llevar a cabo este estudio. A Juan Carlos Dzid y Christian Herrera por su apoyo en el trabajo de campo. Este trabajo formó parte de la tesis doctoral dentro del Programa en Ciencias de la Producción y de la Salud Animal de la Facultad de Medicina Veterinaria y Zootecnia de la Universidad Nacional Autónoma de México.

\section{Literatura Citada}

Achan G., Febles G., Ruíz T., and Noda A., 2011. Performance of tree species in two arboretums of the Institute of Animal Science. Cuban Journal of Agricultural Science. 45 (4): 439
(Gerber et al., 2013), in addition to the nematicide effect, and which would contribute to decreasing the load of intestinal parasites (Hoste et al., 2006; Mueller, 2006). The fodder species found, clearly differentiated by type of community, may represent an offer of food for the bovine livestock with different nutritional characteristics that could be complemented throughout the year for a better distribution of the availability of fodder.

In this manner, the nutritional potential of the secondary vegetation described before constitutes a potential of use for grazing in this type of plant communities. Avoiding felling to induce the monocrop of improved pasturelands, when promoting this grazing in the natural vegetation, in addition to providing complementary fodder in critical times, allows its fodder species' structure and diversity to foster a higher connectivity between fragments of primary vegetation; the very presence of secondary vegetation optimizes environmental services such as nitrogen fixing, phosphorus solubility, and improves the biological activity of the soil and offers habitat for wild fauna (Murgueitio et al., 2008; 2011).

\section{Conclusions}

The different successional states in the vegetation of the medium sub-deciduous rainforest influenced the quality and quantity of potential food for bovine livestock.

The successional state with greater time of abandonment presented a better nutritional quality, measured through the ruminal degradability and concentration of metabolizable energy, which is complemented in the amount of potential phytomass with the youngest successional states where the Poaceas dominate.

The vegetation of the intermediate states of succession in the dry season can be strategic for the survival of the livestock due to the higher abundance of fodder species that are resistant to drought, which is why the secondary vegetation offers sufficient food and of high quality in the different successional states of the sub-humid tropics, with adjusted animal loads for the yield of potential phytomass. 
-444 .

Adjorlolo L., Amaning-Kwarteng, and Fianu F., 2004. Preference of sheep for three forms of Mucuna forage and the effect of the supplementation with Mucuna forage on the performance of sheep. Tropical Animal Health and Production. $36: 145-156$.

Alonso M. A., Torres F. J., Sandoval C. A., Hoste H., Aguilar A. J., and Capetillo C. M. 2009. Sheep preference for different tanniniferous tree fodders and its relationship with in vitro gas production and digestibility. Animal Feed Science and Technology. 151: 75 - 85.

Álvarez M., Córdoba S., Escobar F., Fagua G., Gast F., Mendoza H., Ospina M., Umańa A. M., y Villareal H. 2006. Manual de métodos para el desarrollo de inventarios de biodiversidad. Instituto de Investigación de Recursos Biológicos Alexander von Humboldt. Bogotá, Colombia.

Ankom Technology. S/F. Neutral Detergent Fiber in Feeds - Filter Bag Technique (for A200 and A200I). NDF Method Method 6.

Andrade H., Esquivel H., y Ibrahim M., 2008. Disponibilidad de forrajes en sistemas silvopastoriles con especies arbóreas nativas en el trópico seco de Costa Rica. Zootecnia Tropical. 26 (3): 289 - 292.

AOAC International, 2000. Official Methods of Analysis. 17th ed. AOAC Int., Gaithers-burg, MD.

Ayala A. J., Cetina R., Capetillo C., Zapata C., y Sandoval C. A. 2006. Composición química-nutricional de árboles forrajeros. Universidad Autónoma de Yucatán. Mérida, Yucatán, México. https://www.researchgate.net/publication/277141987_Composicion_Quimica-Nutricional_de_ Arboles_Forrajeros. Fecha de consulta: 20 de octubre de 2015.

Bello J., Gallina S., y Equihua M. 2001. Characterization and habitat preferences by white-tailed deer in México. Journal of Range Management. 54: 537 - 545.

Bautista F., Delfín H., Delgado M., y Palacio J. 2004. Técnicas de muestreo para manejadores de recursos naturales. Universidad Nacional Autónoma de México, Universidad Autónoma de Yucatán, Consejo Nacional de Ciencia y Tecnología e Instituto Nacional de Ecología, México. http://www2.inecc. gob.mx/publicaciones/download/526.pdf Fecha de consulta: 25 de julio de 2015.

Bonham C, 1989. Measurements for terrestrial vegetation. 1st Edition. John Wiley and Sons, Inc. ISBN 0-71-04880-1. EUA. 352 P.

Cab F., Ortega M., Quero A., Enríquez J., Vaquera H., y Carranco M. 2015. Composición química y digestibilidad de algunos árboles tropicales forrajeros de Campeche, México. Revista Mexicana de Ciencias Agrícolas Pub. Esp. 11:2199-
2204.

Castellón M., y Elías A. 2015. Evaluación del peso de inicio en toros en ceba con dietas basadas en foraje de Panicum maximum, cutícula de maní (Arachis hypogaea) y un suplemento proteico-energético. Revista Cubana de Ciencia Agrícola. 49:1 http://www.ciencia-animal.org/revista-cubana-de-ciencia-agricola/articulos/T49-N1-A2015-P23-ME-Castellon. pdf. Fecha de consulta 22 de noviembre de 2015.

Colwell R. K. 2013. Estimate S: Statistical estimation of species richness and shared species from samples. Version 9.1.

CICC. 2009. 5a Comunicación Nacional ante la Convención Marco de las Naciones Unidas sobre el Cambio Climático. Comisión Intersecretarial de Cambio Climático. http:// www2.inecc.gob.mx/publicaciones/download/685.pdf . Fecha de consulta: 07 de mayo de 2015.

CICY. 2010. Flora de la Península de Yucatán. Catálogo de la Flora. http://www.cicy.mx/sitios/flora\%20digital/indice_ busqueda.php. Fecha de consulta: 18 de enero de 2015.

CONAGUA. 2015. Cominsión Nacional del Agua. Península de Yucatán. http://www.conagua.gob.mx/ocpy/ Fecha de consulta: 23 de noviembre de 2015 .

Dulphy J. P., and Demarquilly C. 1994. The regulation and prediction of feed intake in ruminants in relation to feed characteristics. Livestock Production Science. 39: 1-13.

ECOCROP. 2007. Food and Agriculture Organization of the United Nations. http://www.fao.org/ag/AGP/AGPC/doc/ GBASE/Default.htm. Fecha de consulta: 06 de diciembre de 2016.

Escamilla B. A., Quintal T. F., Medina L. F., Guzman A., Pérez E., y Calvo I. L. 2005. Relaciones suelo-planta en ecosistemas naturales de la península de Yucatán: comunidades dominadas por palmas. In: Bautista F, Palacio G editores Caracterización y manejo de los suelos de la península de Yucatán: Implicaciones Agropecuarias, Forestales y Ambientales. Universidad Autónoma de Campeche, Universidad Autónoma de Yucatán, Instituto Nacional de Ecología. 159-172.

FAO. 2009. El estado mundial de la agricultura y la alimentación. Organización de las Naciones Unidas para la Agricultura y la Alimentación. Roma, Italia. https://www.fao.org. br/download/i0680s.pdf. Fecha de consulta: 25 de mayo de 2015.

FAO. 2013. Tackling climating change through livestock. A global assessment of emissions and mitigation opportunities. Food and Agriculture Organization of the United Nations. Rome, Italy. http://www.fao.org/3/i3437e.pdf. Fecha de consulta: 9 de agosto de 2015.

Ferguson G., Diemont A., Alfaro A., Martin F., Nahed T., Álvarez S., et al. 2013. Sustainability of holistic and conventional cattle ranching in the seasonally dry tropics of Chiapas, 
México. Agricultural Systems. 120: 38-48.

Flores S., y Espejel I., 1994. Tipos de vegetación de la Península de Yucatán. Universidad Autónoma de Yucatán, Dirección General de Extensión.

Flores S. 2001. Leguminosae. Florística, Etnobotánica y Ecología. Etnoflora Yucatanense. Fascículo 18. Universidad Autónoma de Yucatán. Facultad de Medicina Veterinaria y Zootecnia. Yucatán, México.

Flores S., y Bautista F. 2005. Inventario de plantas forrajeras utilizadas por los Mayas en los paisajes geomorfológicos de la peninsula de Yucatán. In: Bautista B, Palacio G editores. Caracterización y manejo de los suelos de la península de Yucatán: Implicaciones Agropecuarias, Forestales y Ambientales. Universidad Autónoma de Campeche, Universidad Autónoma de Yucatán, Instituto Nacional de Ecología, México. 209-219.

Flores S., y Bautista F. 2012. El conocimiento de los mayas yucatecos en el manejo del bosque tropical estacional: las plantas forrajeras. Revista Mexicana de Biodiversidad. 83(2): 503-518.

Garcia E., y CONABIO. 1998. Climas (Clasificación de Köppen, modificado por García), escala 1:1 000 000. Comisión Nacional para el Conocimiento y Uso de la Biodiversidad, Mexico.

Gerber P., Hederson B., y Makkar H. 2013. Mitigación de las emisiones de gases con efecto invernadero en la producción ganadera. Organización de las Naciones Unidas para la Agricultura y la Alimentación. Roma, Italia. UK. http://www. fao.org/docrep/019/i3288s/i3288s.pdf. Fecha de consulta: 13 de noviembre de 2015.

Gleen-Lewin D. C., Peet R. K., and Veblen T. T. 1992. Plant succession. Theory and prediction. Chapman \& Hall. Cambridge, UK. 359 p.

González P., Torres J., and Sandoval C. 2014. Adapting bite coding grid from small ruminants browsing a deciduous tropical forest. Tropical and Subtropical Agroecosystems, 17: 63-70.

Gutiérrez B., Ortiz D., Flores J., y Zamora C. 2012. Diversidad, estructura y composición de las especies leñosas de la selva mediana subcaducifolia del Punto de Unión Territorial (PUT) de Yucatán, México. Polibotánica. 33: 151 - 174.

Hoste H., Jackson F., Athanasiadou S., Thamsborg S. M., and Hoskin S. O. 2006. The effects of tannin-rich plants on parasitic nematodes in ruminants. Trends in Parasitology 22: 253-261.

Ku J. C., Ramírez L., Jiménez G., Alayón J. A., et al. 1999. Árboles y Arbustos para la producción animal en el trópico mexicano. En: Agroforestería para la Producción Animal en Latinoamérica. Estudio FAO Producción y Sanidad Animal 143, Roma, Italia.
Kovach L. 2007. MVSP-A MultiVariate Statistical Package for Windows, ver. 3.1. Kovach Computing Services, Pentraeth, Wales, U.K.

Jackson F., Barry T., Lascano C., and Palmer B. 1996. The extractable and bound condensed tannin content of leaves from tropical tree, shrub, and forage legumes. Journal of the Science Food and Agriculture. 71 (1): 103-110.

LEAD. 2006. The Livestock Environment and Development. Livestock long shadow. Environmental issues and option. Food and Agriculture Organization of the United Nations. http://www.fao.org/docrep/010/a0701e/a0701e00.HTM. Fecha de consulta: 28 de octubre de 2015.

Lecco. 2013. TruMac CN. Carbon/Nitrogen Determinator. Instruction Manual. Version 1.3x. Part number 200-725 No. HQ-Q-994. Lecco Corporation.

López M., Rivera J., Ortega L., Escobedo J., Magańa M., Sanginés R., and Sierra A. 2008. Quintana Roo Nutritional composition and antinutritional factor content of twelve native forage species from northern Quintana Roo, Mexico. Técnica Pecuaria México. 46 (2): 205-215.

Magurran A. E. 1988. Ecological Diversity and its Measurement. London, Chapman and Hall. 178 P.

Makkar H., and Becker K. 1993. Vanillin-HCl method for condensed tannins: efect of organic solvents used for extraction of tannins. Journal of Chemical Ecology. 19 (4): 613-621.

Mizrahi A., Ramos M., and Osorio J. 1997. Composition, structure and mangament potential of secondary dry tropical vegetation in two abandoned henequen plantations of Yucatan, México. Forest Ecology and Mangement 94: 79-88.

Mueller-Dombois D., and Ellenberg H. 1974. Aims and methods of vegetation ecology. Jhon Wiley \& Sons, New York. USA. 547 p.

Mueller, H. 2006. Review. Unravelling the conundrum of tannins in animal nutrition and health. Journal of the Science of Food and Agriculture. 86: 2010-2037.

Murgueitio, E., Ibrahim M., Molina H., Molina D., y Molina J. 2008. Ganadería del futuro: Investigación para el desarrollo. Fundación CIPAV. Murguetitio E., Cuartas C., y Naranjo J. Calí, Colombia. http://www.cipav.org.co/pdf/noticias/PaginasSSPCIPAV.pdf. Fecha de consulta: 10 de marzo de 2015.

Murgueitio E., Call Z., Uribe F., Calle A., and Solorio B., 2011. Native trees and shrubs for the productive rehabilitation of tropical cattle ranching lands. Forest Ecology and Management 261: 1654-1663.

Nahed J., Valdivieso A., Aguilar R., Cámara J., and Grande D. 2013. Silvopastoral systems with traditional mangament in southeastern México: a prototype of livestock agroforestry for cleaner production. Journal for Cleaner Production 57: 266-279. 
NAS (National Academic Science). 1979. Tropical legumes: resources for the future. Washington D. C. $331 \mathrm{p}$.

Ørskov, E., Hovell F., and Mould F. 1980. The use of the nylon bag technique for the evaluation of feedstuffs. Tropical Animal Production. 5 (3): 195-213.

Osorio A., y Marfil A., 1999. Caracterización de la ganadería lechera del estado de Yucatán, México. Revista Biomédica $10,217-227$.

Palma J., Nahed J., y Sanginés L., 2011. Agroforestería pecuaria en México. Instituto Nacional de Ciencias Médicas y Nutrición Salvador Zubirán. México.

Pettit J., Casanova F., Solorio J., y Ramírez L. 2011. Producción y calidad de hojarasca en bancos de forraje puros y mixtos en Yucatán, México. Revista Chapingo. Serie Ciencias Forestales y del Ambiente. 17 (1): 165-178. http://www.redalyc. org/articulo.oa?id=62917370015. Fecha de consulta: 04 de diciembre de 2016.

Pinto R., Gómez H., Martínez B., Hernández A., Medina F., Ortega L., and Ramírez L. 2004. Forage pecies utility in silvopastoral system in the valley central of Chiapas. Avances en Investigación Agropecuaria. 8 (2):53-67.

Rico-Gray V., Chemás A., and Mandujano S., 1991. Uses of tropical deciduos forest species by the yucatecan maya. Agroforestry Systems 14: 149-161.

Rojas S., Olivares J., Quiroz F., Villa A., Cipriano M., Camacho L., and Reynoso A. 2016. Diagnosis of the palatability of fruits of three fodders trees in ruminants. Ecosistemas y Recursos Agropecuarios 3 (7): 121-127.

Romero A., and Duarte J. 2012. Identification and nutritional valuation of frequently consumed plant species by sheep and goat grazing on the Tatacoa desert, Huila, Colombia. Agroforestería Neotropical. 2 (1). 2012. http://repository.ut.edu. co/handle/001/1282. Fecha de consulta: 04 de diciembre de 2016.

Sadi S., Shanmugavelu, Azizan A., Abdullah F., Wan M., and Humrawali K. 2015. Effects of Ischaemum rugosum-Gliricidia sepium diet mixtures on growth performance, digestibility and carcass characteristics of Katjang crossbred goat. Journal of Tropical Agricultural and Food Science. 43 (2): 179-190.

SAS (Satistical Analysis Systems Institute). 2000. Users Guide Statistic, SAS Institute, Cary, North Carolina. (Version 8,1).
$646 \mathrm{p}$.

Sauvant D., and Van Milgen J. 1995. Dynamic aspects of carbohydrate and protein breakdown and the associated microbial matter synthesis. In: W. von. Englehardt S, Leonhard-Marek, Breves G, Diesecke D (eds). Ruminant Physiology: Digestion, Metabolism, Growhth and Reproduction. Ferdinand Enke Verlag, Stuttgart, Germany. pp: 71-91.

Sørensen T. 1948. A method of establishing groups of equal amplitude in plant sociology based on similarity of species content and its application to analyses of the vegetation on Danish commons. Biologiske Skrifter (K Danske Vidensk. Selsk. NS). 5: 1-3.

Sosa R., Sansores L., Zapata B., y Ortega R. 2000. Composición botánica y valor nutricional de la dieta de bovinos en un área de vegetación secundaria en Quintana Roo. Técica Pecuaria en México. 38 (2): 105-117.

Van Soest P. J., Robertson J. B., and Lewis B. A. 1991. Methods for dietary fiber, neutral detergen fiber, and nonstarch polysaccharides in relation to animal nutrition. Journal of Dairy Science. 74 (10): 3583-3597.

Vásquez F., Pezo D., Mora-Delagado J., y Skarpe Ch. 2012. Selectividad de especies forrajeras por bovinos en pastizales seminaturales del trópico centroamericano: un estudio basado en la observación sistemática del pastoreo. Zootecnia Tropical. 30 (1): 63-80.

Velázquez M., López O., Hernández M., Díaz R., Pérez E., and Gallegos S. 2010. Foraging behavior of heifers with or without social models in an unfamilar site containing high plant diversity. Livestock Sicence. 131: 73-82.

Velázquez M., López S., Hernández O., Díaz P., Pérez S., and Gallegos J. 2011. Chemical and nutritional characterization of different species native to a site grazed by calves in north Veracruz. Abanico Veterinario. 1 (1): 16-20.

Villegas D., Bolaños M., y Olguín P. 2001. Ganadería en México. I.5.1. Temas selectos de geografía en México. Universidad Nacional Autónoma de México. Instituto de Geografía. Plaza y Valdez Editores, SA de CV. 157 p.

Zamora P., García G., Flores J., y Ortíz J. 2008. Estructura y composición florística de la selva mediana subcaducifolia en el sur del estado de Yucatán, México. Polibotánica: 26, 3966.

Zamora C., Flores G., y Ruenes M., 2009. Flora útil y su manejo en el cono sur del Estado de Yucatán, México. Polibotánica. 28: $227-250$. 